\title{
AN EVALUATION OF THE GREENHOUSE GAS REDUCTION POTENTIAL THROUGH THE CO-FIRING OF COAL AND MICROALGAE BIOMASS
}

\author{
NOKUTHULA E. MAGIDA, BEN ZEELIE \& GARY DUGMORE \\ InnoVenton: NMU Institute for Chemical Technology, Nelson Mandela University, Port Elizabeth, \\ Republic of South Africa
}

\begin{abstract}
South Africa is heavily depended on coal to meet its energy requirements. There is therefore a significant incentive to develop and implement clean coal combustion technologies that would reduce the environmental impact of energy generation from coal. For power generation, the co-firing of renewable biomass fuels at conventional coal-fired power stations is recognised as one of the lowercost, lower-risk options to achieve significant greenhouse gas (GHG) emission reductions. The aim of study was to evaluate the GHG emission reduction potential through the co-firing of coal and microalgae biomass. Coal to microalgae mass ratios of 95:5 and 90:10 were prepared, combusted in a fixed-bed reactor and compared to pure coal. The emission concentration of $\mathrm{CO}_{2}(\%), \mathrm{NOx}(\mathrm{ppm})$ and $\mathrm{SO}_{2}$ (ppm) of coal and Coalgae ${ }^{\mathbb{B}}$ blends (a composite material containing coal and microalgae biomass) were measured during the combustion of the three materials using Lancom 4 portable flue gas analyser. The results have shown significant reduction in $\mathrm{CO}_{2}, \mathrm{SO}_{2}$ and $\mathrm{NOx}$ levels when Coalgae ${ }^{\circledR}$ was burned. Emission reductions of $8.4 \%, 17.5 \%$ and $10.4 \%$ for $\mathrm{CO}_{2}, \mathrm{SO}_{2}$ and $\mathrm{NOx}$ were achieved with Coalgae ${ }^{\circledR}$ $5 \%$, respectively. Reductions of $10.7 \%, 21.4 \%$ and $15.4 \%$ for $\mathrm{CO}_{2}, \mathrm{SO}_{2}$ and $\mathrm{NOx}$ were achieved with Coalgae ${ }^{\circledR} 10 \%$, respectively. Moreover, the combustion efficiency of Coalgae ${ }^{\circledR}$ was maintained at $97.60 \%$ slightly below $99.26 \%$ (1.7\% difference) obtained from the pure coal. Based on the above findings, the co-firing of coal and microalgae biomass was necessary for the reduction of GHG emissions. As such, Coalgae ${ }^{\circledR}$ can be considered as an alternative fuel in any coal driven process for energy generation.

Keywords: coal, Coalgae ${ }^{\circledR}$, microalgae biomass, co-firing, greenhouse gas emissions.
\end{abstract}

\section{INTRODUCTION}

The global energy demand is increasing significantly and this is unlikely to change unless the developing countries change their existing laws and strategies, especially those related to greenhouse gas (GHG) emissions. The increase in energy demand leads to increasing environmental pollution concerns emanating from the use of fossil fuels, particularly coal. Coal is the primary source of energy in most parts of the world including South Africa. Coal is responsible for at least $29.2 \%$ of the world's primary energy needs [1]. In 2015, about $68.4 \%$ of the energy consumed in South Africa was generated from coal with rest of the other sources contributing a combined $31.6 \%$ [1].

Coal is largely used for energy generation due to its accessibility, affordability and availability, particularly in South Africa and other leading coal producing countries. However, the combustion of coal poses several environmental challenges which contributes directly to climate change which in turn is responsible for receding of glaciers, rise in sea levels and putting human health at risks [2]. Coal combustion produces greenhouse gas (GHG) emissions such as carbon dioxide $\left(\mathrm{CO}_{2}\right)$, carbon monoxide $(\mathrm{CO})$, sulphur dioxide $\left(\mathrm{SO}_{2}\right)$, nitrogen oxides (NOx), nitrous oxide $\left(\mathrm{N}_{2} \mathrm{O}\right)$ and particulate matter (PM). Renewable energy resources have gained much attention as alternative fuels to fossil fuels. Biomass combustion technologies can be used alternatively to coal combustion to reduce the GHG effect. However, biomass fuels are often co-fired with coal due to their lower energy density 
[3]. Biomass co-firing is a potential GHG emissions reduction technology with lower cost which can be used in existing coal-firing boilers without substantial modifications [4]. Additionally, biomass is considered a carbon neutral in such that the $\mathrm{CO}_{2}$ produced when it is burned is part of the active cycle, unlike the fossil $\mathrm{CO}_{2}$ which forms the GHG effect [5].

Numerous studies have been done on coal and biomass co-firing, algae included. However, there is less to nothing reported on GHG emissions in South Africa. Algae cofiring is considered a potential clean coal technology due to advantages such as high growth rate periodically, less competition with food stocks and high carbon content which can be approximately $50 \mathrm{wt} . \%$ [6], [7]. However, the carbon content varies with different species of microalgae. Kucukvar and Tatari [7], reported increased concentrations of $\mathrm{CO}_{2}$ on their LCA studies for coal and dry microalgae co-firing at ratios of $0 \%$ to $100 \%$. Nevertheless, Kadam [8], reported $30-40 \%$ decrease in $\mathrm{CO}_{2}$ when also co-firing coal with microalgae. Therefore, there is still a need for more research on emissions from coal and biomass co-firing to decide on implementing this technology or not.

This work aimed to evaluate the potential of reducing GHG emissions through co-firing of coal and microalgae biomass. Substituting small portions of coal with microalgae biomass has the capability to enhance the combustion behaviour of coal and mitigate the GHG emissions, particularly $\mathrm{CO}_{2}$.

\section{EXPERIMENTAL}

\subsection{Materials}

The bituminous lumpy coal and microalgae were supplied by Eskom and InnoVenton (both in South Africa), respectively. Coal was pulverised and sieved to $150 \mu \mathrm{m}$, and then mixed with microalgae slurry to prepare Coalgae ${ }^{\circledR}$ blends of 95:5 and 90:10 on mass basis. Coalgae ${ }^{\circledR}$ is a newly formed fuel after mixing coal with microalgae. Pure coal was used for referencing. The proximate and ultimate analyses of pure coal fines and Coalgae ${ }^{\circledR}$ blends are summarised in Table 1.

Table 1: Fuel properties.

\begin{tabular}{|l|c|c|c|}
\hline & $\begin{array}{c}\text { Pure coal } \\
(100: 0)\end{array}$ & $\begin{array}{c}\text { Coalgae }^{\circledR} \\
(95: 5)\end{array}$ & $\begin{array}{c}\text { Coalgae }^{\circledR} \\
(90: 10)\end{array}$ \\
\hline Proximate analysis (wt.\%, ad) \\
\hline Moisture & 4.61 & 4.68 & 5.10 \\
\hline Volatile matter & 24.52 & 26.89 & 29.07 \\
\hline Ash & 15.01 & 14.92 & 14.67 \\
\hline Fixed Carbon (diff) & 55.88 & 53.50 & 51.16 \\
\hline Ultimate analysis (wt.\%, ad) & 65.36 & 63.39 & 61.50 \\
\hline Carbon & 5.04 & 5.06 & 5.10 \\
\hline Hydrogen & 1.97 & 2.74 & 2.76 \\
\hline Nitrogen & 0.49 & 0.47 & 0.40 \\
\hline Sulphur & 12.13 & 13.42 & 15.57 \\
\hline Oxygen (diff) & 25.89 & 25.65 & 25.41 \\
\hline HHV (MJ/kg) &
\end{tabular}




\subsection{Experimental set-up and procedure}

Combustion experiments were carried out in a laboratory-scale vertical down firing fixed bed reactor, as shown in Fig. 1. The reactor has a length of $33 \mathrm{~cm}$ with an inner diameter of 4.1 $\mathrm{cm}$ and outer diameter of $4.9 \mathrm{~cm}$. The reactor was fitted with an air supply line situated below the grate. The flow of air into the reactor was regulated through a flow meter. Above the grate is the ignitor inlet operated manually to ignite the fuel, suspended onto the grate, inside the reactor. During combustion, the flue gas is directed towards the chimney on top of the reactor. Also at the top of the reactor there is a gas flow outlet from which the gas emissions were measured.

To carry out the combustion experiments, $200 \mathrm{~g}$ of the fuel was loaded onto the grate in the reactor chamber. After loading the substrate, air was pumped into the reactor at a controlled rate, followed by manual ignition of the fuel. During combustion experiment the temperature inside the reactor was measured, followed by measuring the concentration of $\mathrm{CO}_{2}(\%), \mathrm{NOx}(\mathrm{ppm})$ and $\mathrm{SO}_{2}(\mathrm{ppm})$, as well as measuring the mass reduction $(\mathrm{g})$. Gas emissions were measured at the flue gas outlet every minute using Lancom 4 portable flue gas analyser.

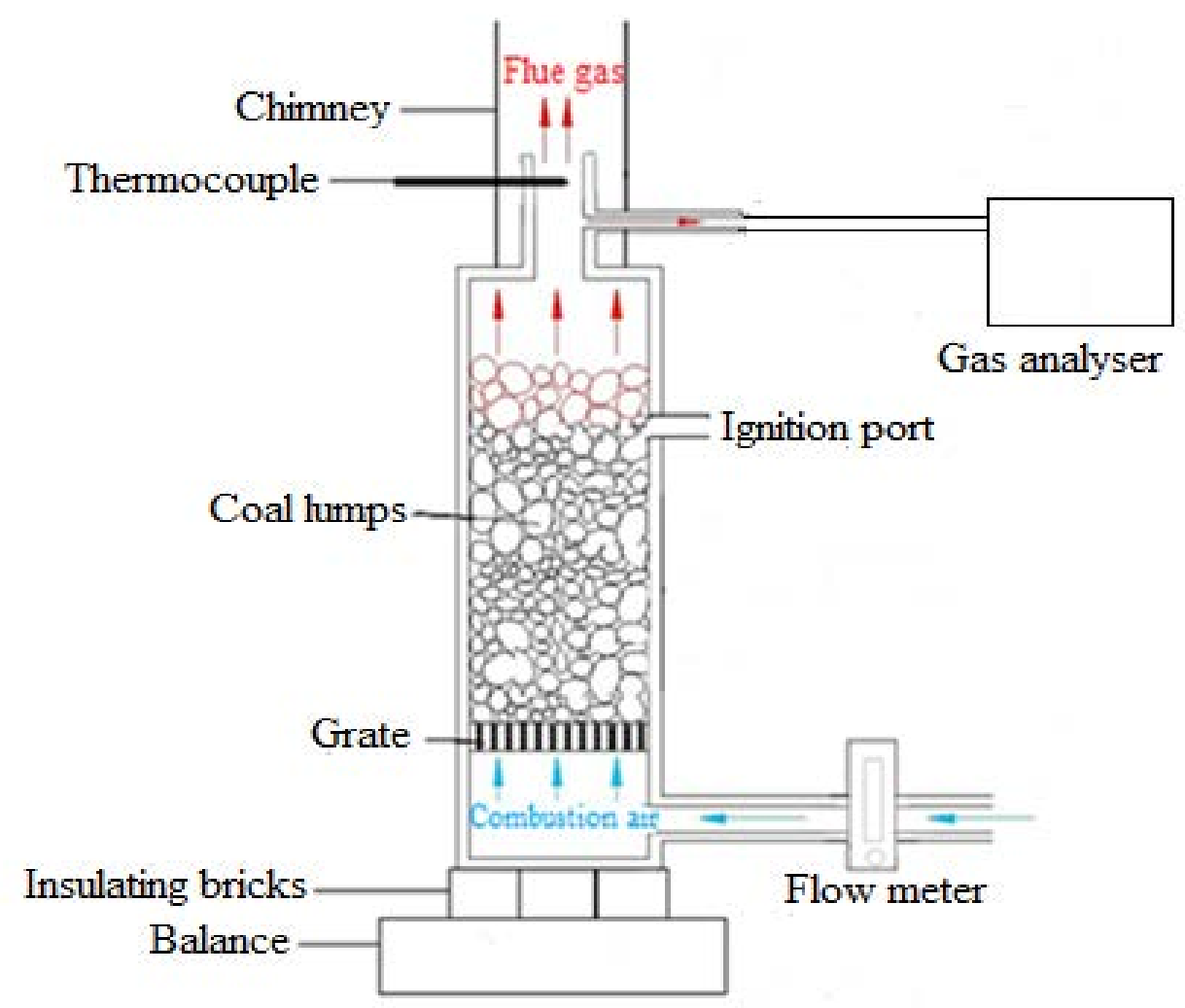

Figure 1: Experimental combustion set-up. 


\section{RESULTS AND DISCUSSION}

\subsection{Co-firing of coal with microalgae biomass}

The co-firing of coal with microalgae biomass have been studied and compared with combustion of pure coal. The combustion temperature was measured at the reactor exit and results are depicted in Fig. 2. The combustion temperature of the three materials showed two peaks; the first peak can be associated to volatile release, while the second peak can be associated to char combustion. The release of volatiles became faster as the content of microalgae increased in the blends, showing the first peak around 15 minutes for Coalgae ${ }^{\circledR}$ $5 \%$ and around 20 minutes for Coalgae ${ }^{\mathbb{R}} 10 \%$. The second peak shifted towards lower temperatures as the content of microalgae was increased in the blends.

The maximum temperatures reached by the second peak of Coalgae ${ }^{\circledR} 10 \%$ and $5 \%$ were $524^{\circ} \mathrm{C}$ and $518^{\circ} \mathrm{C}$, respectively. These temperatures shifted towards lower temperatures by up to $15 \%$ from $607^{\circ} \mathrm{C}$ reached when burning pure coal. This can be attributed to decrease in comparative carbon content. However, the first peak of $10 \%$ blend is slightly higher than that of $5 \%$ blend and this may be due to increase in volatile content leading to easy ignition. The combustion of Coalgae ${ }^{\circledR}$ blends was faster than that of coal and this was shown by rapid loss of weight as depicted in Fig. 3. The fast combustion can be attributed to simultaneous combustion of volatiles and char. The combustion of blends took about 1 hour 40 minutes and 1 hour 50 minutes for Coalgae ${ }^{\circledR} 5 \%$ and $10 \%$, respectively.

The effect of co-firing coal with microalgae on $\mathrm{CO}_{2}$ concentration was measured and is depicted in Fig. 4. The $\mathrm{CO}_{2}$ concentration decreased as the content of microalgae was increased in Coalgae ${ }^{\circledR}$ blends. The $\mathrm{CO}_{2}$ concentrations of $15.44 \%$ and $15.04 \%$ were measured when burning Coalgae ${ }^{\circledR} 5 \%$ and $10 \%$, reaching reductions of $8.4 \%$ and $10.7 \%$, respectively.

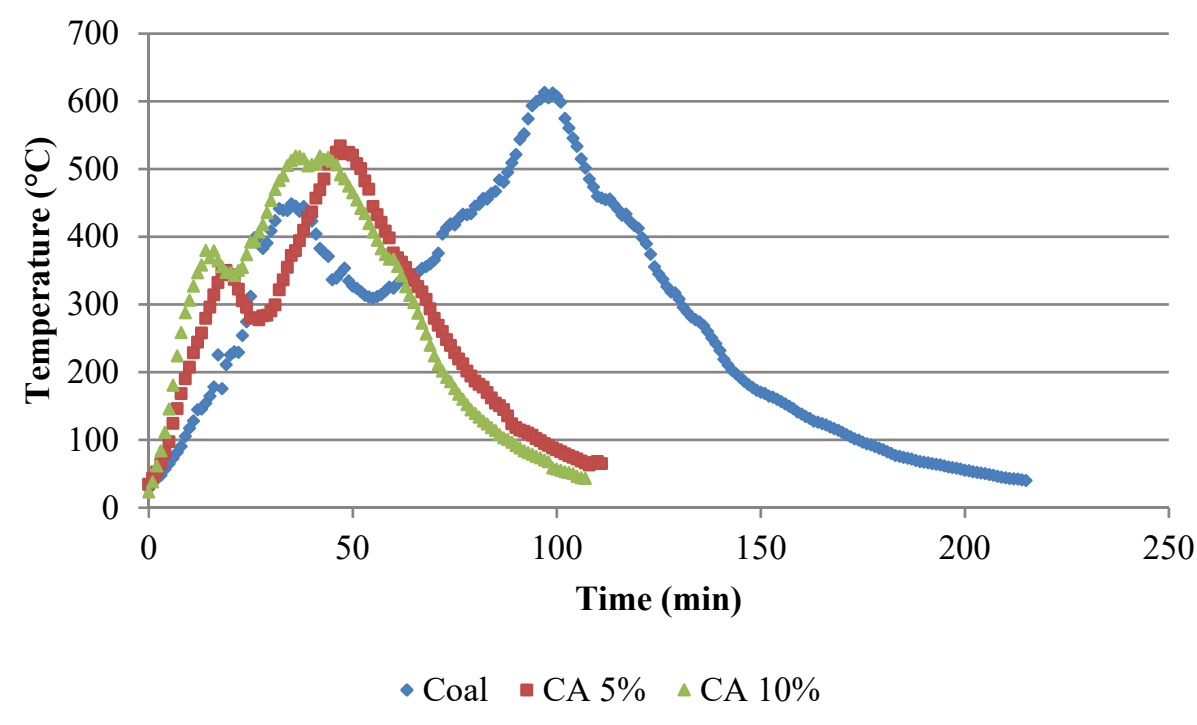

Figure 2: Combustion temperature at the reactor outlet. 


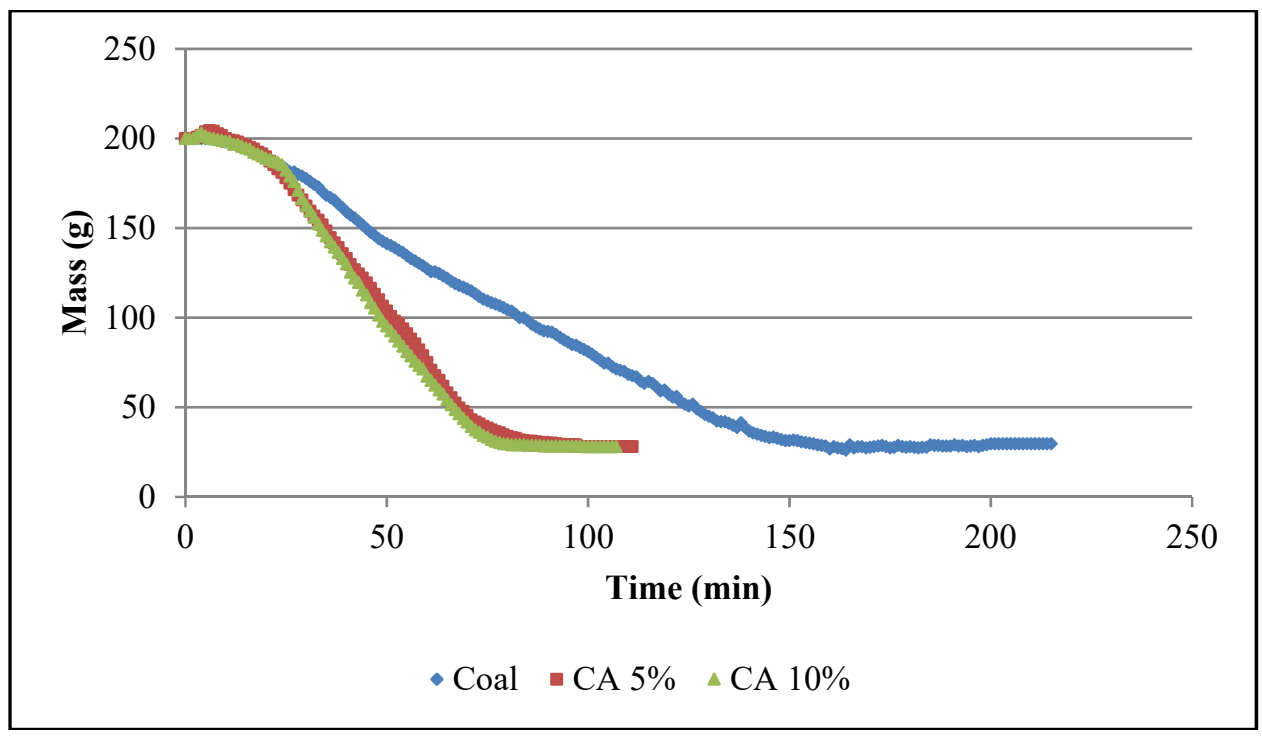

Figure 3: Mass reduction curve.

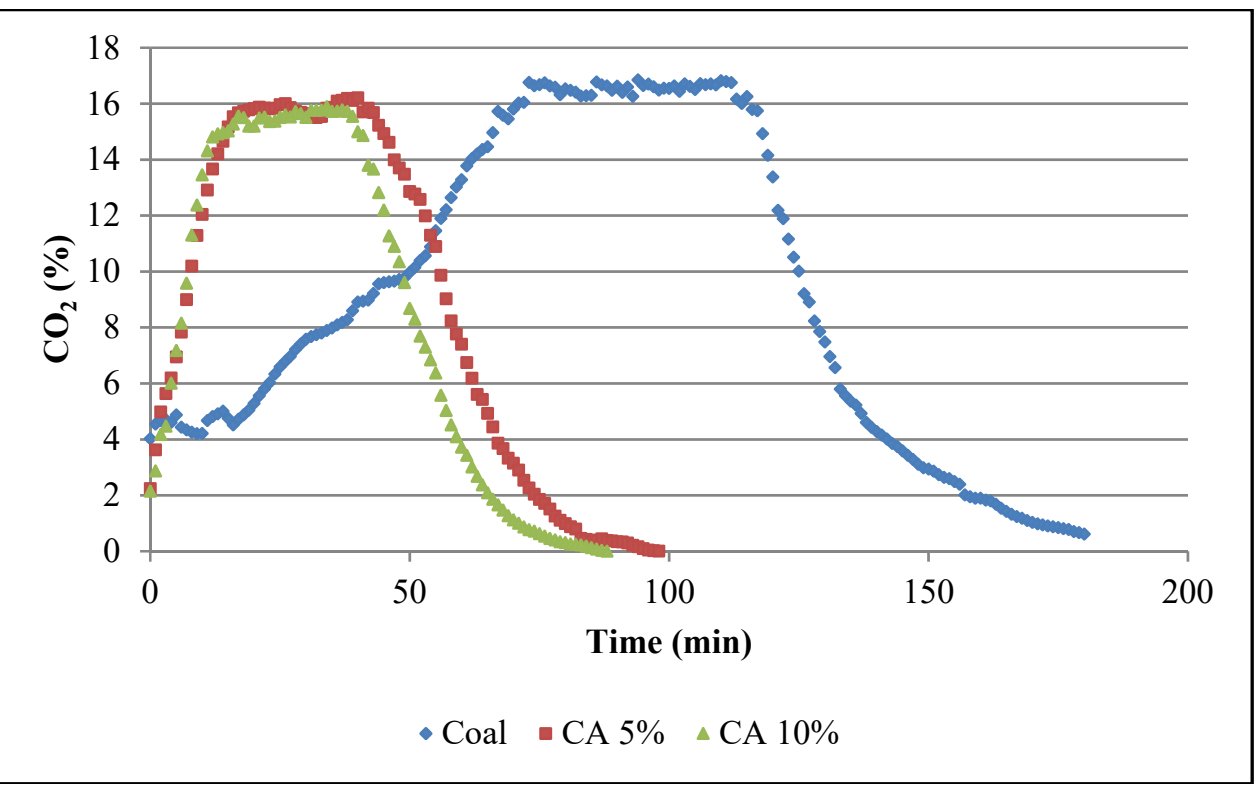

Figure 4: $\mathrm{CO}_{2}$ concentration measured over time.

The total $\mathrm{CO}_{2}$ emissions of $382.64 \mathrm{~g}$ and $330.22 \mathrm{~g}$ were obtained when burning Coalgae ${ }^{\circledR}$ $5 \%$ and $10 \%$, resulting in reductions of $48.4 \%$ and $55.5 \%$, respectively, from $741.28 \mathrm{~g}$ obtained with pure coal, as shown in Table 2 . These reductions can be attributed to decrease 
in comparative carbon content. Comparable results have been reported for microalgae co-firing and biomass co-firing [8], [9].

The effect of co-firing coal with microalgae on emissions of $\mathrm{SO}_{2}$ and $\mathrm{NOx}$ was measured and the results are depicted in Fig. 5. The concentration of $\mathrm{SO}_{2}$ and $\mathrm{NOx}$ were normalised for the dilution effect of the excess air [10]. An oxygen reference of $6 \%$ was used to correct the concentration of $\mathrm{SO}_{2}$ and NOx as shown in eqn (1).

$$
\text { Corrected } \mathrm{ppm}=\text { measured } \mathrm{ppm} \times \frac{20.9-\mathrm{O}_{2} \text { reference }}{20.9-\mathrm{O}_{2} \text { measured }} .
$$

Both $\mathrm{SO}_{2}$ and NOx decreased as the portion of microalgae to coal was increased. $\mathrm{SO}_{2}$ concentrations of $576.89 \mathrm{ppm}$ and $549.58 \mathrm{ppm}$ were measured, achieving reductions of $17.5 \%$ and $21.4 \%$ with Coalgae ${ }^{\circledR} 5 \%$ and Coalgae ${ }^{\circledR} 10 \%$, respectively. Similarly, NOx concentrations of $684.88 \mathrm{ppm}$ and $646.64 \mathrm{ppm}$ were measured, achieving emission reductions of $10.4 \%$ and $15.4 \%$ with Coalgae ${ }^{\circledR} 5 \%$ and Coalgae ${ }^{\circledR} 5 \%$, respectively. Unlike $\mathrm{CO}_{2}$ and $\mathrm{SO}_{2}$, NOx formation seems to have been strongly influenced by excess air and temperature than fuel $\mathrm{N}$ [11]. Fuel $\mathrm{N}$ increased with increasing portion of microalgae to coal, while NOx decreased. In addition to decreasing sulphur content in Coalgae ${ }^{\circledR}, \mathrm{SO}_{2}$ reduction can also be attributed to sulphur retained in Coalgae ${ }^{\circledR}$ ash as shown in Table 3.

Biomass co-firing may result in increased or decreased combustion efficiency compared to pure coal depending on the characteristics of different blends and combustion environments [12]. Combustion efficiency also referred to as burnout of carbon was calculated using eqn. (2) [13].

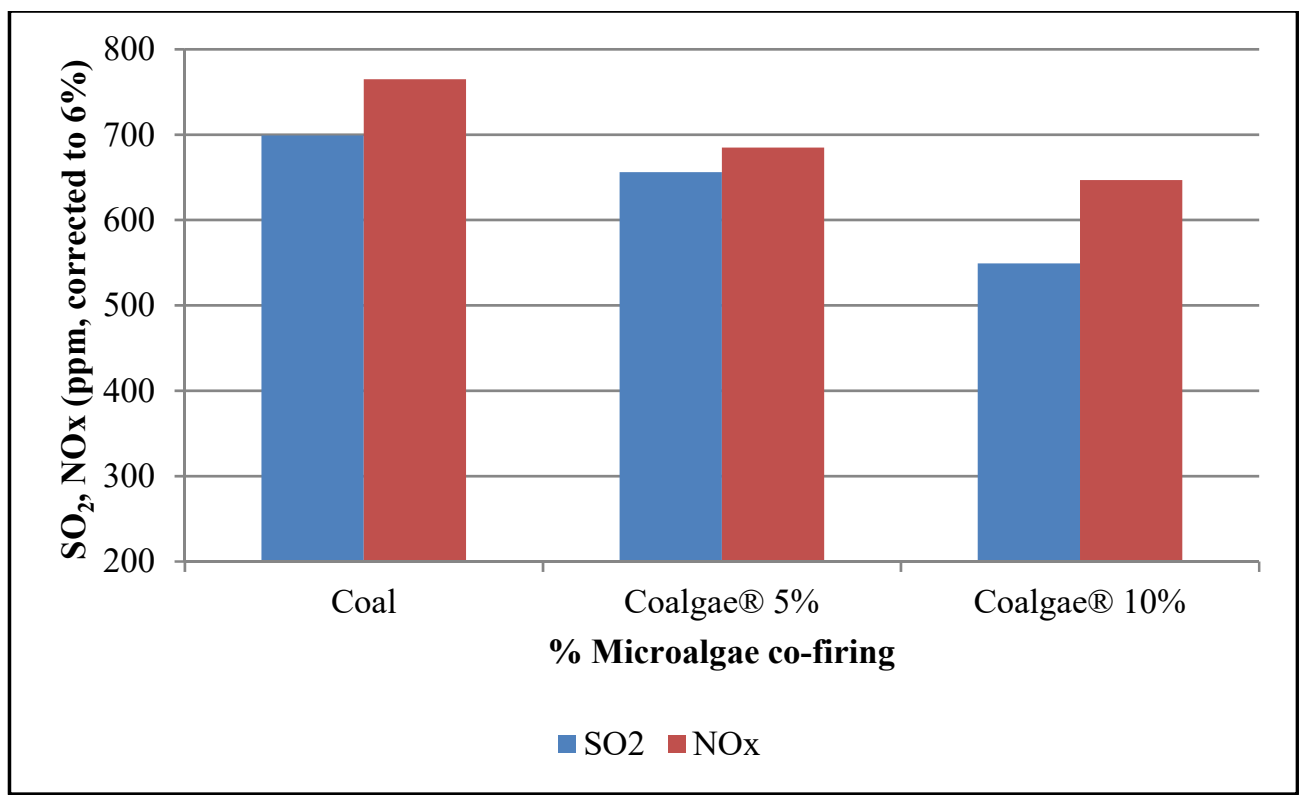

Figure 5: Effect of microalgae on $\mathrm{NOx}$ and $\mathrm{SO}_{2}$ concentrations. 
Table 2: Summary of co-firing results.

\begin{tabular}{|l|c|c|c|c|c|c|}
\hline Fuel & $\begin{array}{c}\text { Temperature } \\
\left({ }^{\circ} \mathrm{C}\right)\end{array}$ & $\begin{array}{c}\mathrm{CO}_{2} \\
(\mathrm{~g})\end{array}$ & $\begin{array}{c}\text { Excess air } \\
(\%)\end{array}$ & $\begin{array}{c}\mathrm{NOx} \\
(\mathrm{ppm})\end{array}$ & $\begin{array}{c}\mathrm{SO}_{2} \\
(\mathrm{ppm})\end{array}$ & $\begin{array}{c}\text { Efficiency } \\
(\%)\end{array}$ \\
\hline Coal $^{\text {Coalgae }}{ }^{\circledR}$ & 607 & 741.13 & 22.49 & 764.78 & 699.49 & 99.26 \\
\hline $5 \%$ & 524 & 382.45 & 28.08 & 684.88 & 576.89 & 97.90 \\
\hline $\begin{array}{l}\text { Coalgae } \\
10 \%\end{array}$ & 518 & 329.74 & 30.84 & 646.64 & 549.58 & 97.60 \\
\hline
\end{tabular}

$$
\text { nc }(\%)=1-\frac{\text { Cunburned }}{\text { Cinlet }} \times 100 \text {, }
$$

where $\mathrm{n}_{\mathrm{c}}$ is the combustion efficiency in $\%, \mathrm{C}_{\text {unburned }}$ is the content of unburned carbon in ash fraction and $\mathrm{C}_{\text {initial }}$ is the content of carbon in a fuel.

Combustion efficiency slightly decreased with increasing content of microalgae in a blend. This is included in Table 2 where summary of co-firing results has been tabulated. The slight decrease in combustion efficiency of blends may be neglected as it only dropped from that of coal by up to $1.7 \%$ at Coalgae ${ }^{\circledR} 10 \%$.

Ash residues that remained after co-firing tests were weighed and analysed. Ash analysis was done to give a partial view on the effect of ash on deposition. XRF analysis was done to determine the mineral composition as shown in Table 3.

The three materials tested composed mainly of $\mathrm{SiO}_{2}$ and $\mathrm{Al}_{2} \mathrm{O}_{3}$ followed by $\mathrm{TiO}_{2}, \mathrm{Fe}_{2} \mathrm{O}_{3}$, $\mathrm{CaO}, \mathrm{K}_{2} \mathrm{O}$ and $\mathrm{P}_{2} \mathrm{O}_{5}$. The ash of coal composed mostly of $\mathrm{SiO}_{2}$ and $\mathrm{Al}_{2} \mathrm{O}_{3}$ which were $55.47 \%$ and $31.33 \%$, respectively. The coal ash contained minor quantities of fluxing compounds $\mathrm{TiO}_{2}(5.24 \%), \mathrm{Fe}_{2} \mathrm{O}_{3}(2.76 \%), \mathrm{CaO}(2.32 \%)$ and $\mathrm{K}_{2} \mathrm{O}(1.15 \%)$; therefore, this ash is relatively refractory and is unlikely to cause slagging and fouling [14]. Similarly, the ash of Coalgae ${ }^{\circledR}$ blends composed mostly of $\mathrm{SiO}_{2}$ and $\mathrm{Al}_{2} \mathrm{O}_{3}$ but these minerals decreased with increasing microalgae blending ratio. On the other side, the fluxing compounds $\left(\mathrm{TiO}_{2}, \mathrm{Fe}_{2} \mathrm{O}_{3}, \mathrm{CaO}\right.$ and $\mathrm{K}_{2} \mathrm{O}$ ) increased with increasing microalgae blending ratio and this might result in increased ash deposition in boilers. Therefore, microalgae proportions above $10 \%$ are not suggested for co-firing with coal, otherwise major modifications on existing boilers would be required.

Table 3: Ash analysis.

\begin{tabular}{|l|c|c|c|}
\hline Compound (\%) & Coal & Coalgae $^{\circledR} 5 \%$ & Coalgae $^{\circledR} 10 \%$ \\
\hline $\mathrm{Al}_{2} \mathrm{O}_{3}$ & 31.33 & 29.22 & 27.57 \\
\hline $\mathrm{SiO}_{2}$ & 55.47 & 45.03 & 42.44 \\
\hline $\mathrm{P}_{2} \mathrm{O}_{5}$ & 0.75 & 2.95 & 4.64 \\
\hline $\mathrm{SO}_{2}$ & 0 & 0.18 & 0.22 \\
\hline $\mathrm{K}_{2} \mathrm{O}$ & 1.15 & 1.37 & 1.93 \\
\hline $\mathrm{CaO}$ & 2.32 & 6.54 & 8.55 \\
\hline $\mathrm{TiO}_{2}$ & 5.24 & 4.12 & 3.99 \\
\hline $\mathrm{Fe}_{2} \mathrm{O}_{3}$ & 2.76 & 8.11 & 8.73 \\
\hline
\end{tabular}




\section{CONCLUSION}

The effect of co-firing coal and microalgae biomass have been studied, using a down firing fixed bed reactor to monitor the emissions of $\mathrm{CO}_{2}, \mathrm{SO}_{2}$ and $\mathrm{NOx}$. The blending of smaller fractions of microalgae $(5 \%$ and $10 \%)$ with coal resulted in enhanced combustion behaviour of a newly formed Coalgae ${ }^{\circledR}$ fuel. This could be due to high volatile content and low ash content in the Coalgae ${ }^{\circledR}$ blends. The total $\mathrm{CO}_{2}$ emissions dropped from $741.13 \mathrm{~g}$ obtained with pure coal to $382.45 \mathrm{~g}$ and $329.74 \mathrm{~g}$ obtained with Coalgae ${ }^{\circledR} 5 \%$ and $10 \%$, respectively. Coalgae $^{\circledR} 10 \%$ showed better combustion characteristics compared to Coalgae ${ }^{\circledR} 5 \%$ and resulted in $55.5 \% \mathrm{CO}_{2}$ reduction, $21.4 \% \mathrm{SO}_{2}$ reduction and $15.4 \%$ NOx reduction. The combustion efficiency achieved with Coalgae ${ }^{\circledR} 10 \%$ was $97.6 \%$ which is only $0.3 \%$ lower from $97.9 \%$ achieved with Coalgae ${ }^{\circledR} 5 \%$. Therefore, Coalgae ${ }^{\circledR}$ co-firing technology has a potential to mitigate greenhouse gas (GHG) emissions. Additionally, Coalgae ${ }^{\circledR} 10 \%$ can be used as an alternative fuel for energy generation in existing boilers. Higher proportions of microalgae to coal are not recommended due to potential damages on boilers caused by ash deposition.

\section{ACKNOWLEDGEMENTS}

This work is supported by the Department of Science and Technology (DST) and Technology Innovation Agency (TIA), and student bursary support from the National Research Foundation (NRF).

\section{REFERENCES}

[1] BP Statistical Review of World Energy, Coal consumption, June 2016. https://www.bp.com/content/dam/bp/pdf/energy-economics/statistical-review2016/bp-statistical-review-of-world-energy-2016-full-report.pdf.

[2] Gullison, R.E., Frumhoff, P.C., Canadell, J.G., Field, C.B., Nepstad, D.C. \& Hayhoe, K., Tropical forests and climate policy. Science, pp. 985-986, 2007.

[3] Khan, A.A., De Jong, W., Jansens, P.J. \& Spliethoff, H., Biomass combustion in fluidized bed boilers: Potential problems and remedies. Fuel Processing Technology, 90, pp. 21-50, 2009.

[4] Fernando, R., Co-firing high ratios of biomass with coal. CCC/194, London, UK, IEA Clean Coal Centre, pp. 1-70, 2012.

[5] Gayan, P., Adaneza, J., De Diego, L.F., Garcia-Labiano, F., Cabanillas, A., Bahillo, A., Aho, M. \& Veijonen, K., Circulating fluidised bed co-combustion of coal and biomass. Fuel, 83, pp. 277-286, 2004.

[6] Demirbas, A. \& Demirbas, M.F., Algae energy: Algae as e new source of biodiesel. Green Energy and Technology. Springer-Verlag: New York, 2010.

[7] Kucukvar, M. \& Tatari, O., A comprehensive life cycle analysis of co-firing algae in a coal power plant as a solution for achieving sustainable energy. Energy, 36, pp. 6352-6357, 2011.

[8] Kadam, K.L., Environmental implications of power generation via coal-microalgae cofiring. Energy, 27, pp. 905-922, 2002.

[9] Pokothoane, P.S., Analysis of co-firing biomass with South African coal in pulverised coal boilers. PhD thesis, University of the Witwatersrand, 2010.

[10] Land Instruments International, Technical Bulletin - Combustion calculations, normalisations and conversions. Combustion and Environmental Monitoring, pp. 117, 2004. 
[11] Khan, A.A., de Jong, W., Jansens, P.J. \& Spliethoff, H., Biomass combustion in fluidized bed boilers: Potential problems and remedies. Fuel Processing Technology, 90, pp. 21-50, 2009.

[12] Sahu, S.G., Chakraborty, N. \& Sarkar, P., Coal-biomass co-combustion: An overview. Renewable and Sustainable Energy Reviews, 39, pp. 575-586, 2014.

[13] Diez, L.I., Lupianez, C., Guedea, I., Bolea, I. \& Romeo, L.M., Anthracite oxycombustion characteristics in a $90 \mathrm{~kW}_{\text {th }}$ fluidized bed reactor. Fuel Processing Technology, 139, pp. 196-203, 2015.

[14] Van Alphen, C., Factors influencing fly ash formation and slag deposit formation (slagging) on combusting a South African pulverised fuel in a $200 \mathrm{MWe}$ boiler. PhD thesis, University of Witwatersrand, 2005. 